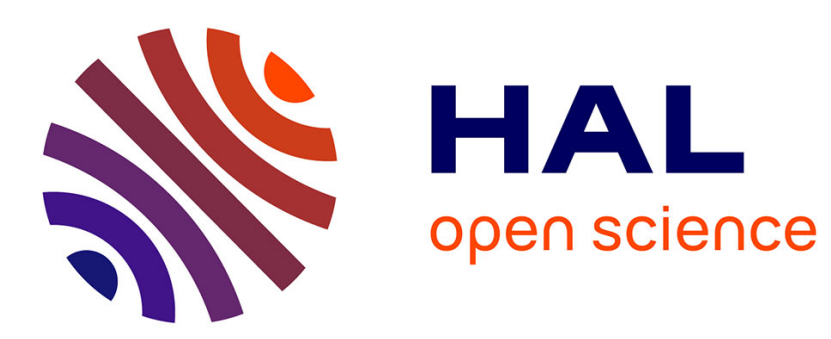

\title{
Leaching of atrazine and deethylatrazine under a vegetative filter strip
}

Jean-Emmanuel Delphin, Jean-Yves Chapot

\section{To cite this version:}

Jean-Emmanuel Delphin, Jean-Yves Chapot. Leaching of atrazine and deethylatrazine under a vegetative filter strip. Agronomie, 2001, 21 (5), pp.461-470. 10.1051/agro:2001137 . hal-00886127

\section{HAL Id: hal-00886127 \\ https://hal.science/hal-00886127}

Submitted on 1 Jan 2001

HAL is a multi-disciplinary open access archive for the deposit and dissemination of scientific research documents, whether they are published or not. The documents may come from teaching and research institutions in France or abroad, or from public or private research centers.
L'archive ouverte pluridisciplinaire HAL, est destinée au dépôt et à la diffusion de documents scientifiques de niveau recherche, publiés ou non, émanant des établissements d'enseignement et de recherche français ou étrangers, des laboratoires publics ou privés. 


\title{
Original article
}

\section{Leaching of atrazine and deethylatrazine under a vegetative filter strip}

\author{
Jean-Emmanuel DELPHIN*, Jean-Yves CHAPOT
}

Équipe Agriculture et Environnement, UMR Vigne et Vins d'Alsace, INRA, 28 rue de Herrlisheim, 68021 Colmar Cedex, France

(Received 4 October 2000; revised 20 March 2001; accepted 19 April 2001)

\begin{abstract}
Vegetative filter strips (VFS) are a device used successfully to control erosion and to reduce the amount of chemical pollutants in surface waters. Part of the surface water runoff is removed by the VFS by infiltration. The objective of this study, conducted for three years under natural conditions, was to investigate the fate and evaluate the leaching of atrazine and deethylatrazine (DEA) transported in runoff effluents and trapped by a VFS. Soil solution was sampled using porous cups installed at two depths at the edge of a VFS established downhill from a maize plot. Drainage volumes were calculated by a generic crop model. The results show that atrazine and DEA in runoff water were transported into the soil by preferential flow. The migration of chemicals was deeper than $60 \mathrm{~cm}$ in 1997 and 1999 but probably did not reach $120 \mathrm{~cm}$. In 1998, atrazine and DEA remained above $60 \mathrm{~cm}$. The migration depth was partly dependent on the soil water content at the time of runoff. The dissipation rate of chemicals in the soil was slower at lower depths. DEA was more persistent than atrazine in the soil solution. The attenuation of atrazine concentration at $60 \mathrm{~cm}$ in the soil solution compared with its concentration in the runoff water ranged from 60 to $95 \%$ depending on the year and the porous cup position. Transport of pesticide occurred after the few weeks following herbicide application on maize but leaching of atrazine and DEA occurred mainly outside the growth season. Calculated leaching amounts of DEA were twice those of atrazine.
\end{abstract}

atrazine / deethylatrazine / vegetative filter strip / porous cup / soil solution

Résumé - Lessivage de l'atrazine et de la dééthylatrazine sous une bande herbeuse. Les bandes herbeuses sont un moyen efficace pour protéger les eaux de surface de contaminations éventuelles par les engrais et les produits de traitement transportés par les eaux de ruissellement. Une partie de ces eaux est piégée par infiltration dans la bande herbeuse. L'objectif de l'étude est de suivre le devenir et d'évaluer le lessivage de l'atrazine et de la dééthylatrazine (DEA) transportées dans les eaux de ruissellement et piégées dans une bande herbeuse installée en bas d'une parcelle en pente cultivée en maïs. La solution du sol est échantillonnée à deux profondeurs à l'aide de bougies poreuses, le lessivage des produits est estimé à partir du drainage calculé par un modèle de bilan hydrique au champ. Les résultats montrent que l'atrazine et la DEA transportées par les eaux de ruissellement migrent dans la bande herbeuse par des transferts préférentiels à une profondeur d'au moins $60 \mathrm{~cm}$ en 1997 et 1999 sans parvenir à $120 \mathrm{~cm}$. En 1998, la descente des pesticides n'atteint pas $60 \mathrm{~cm}$. La profondeur de migration dépend de l'état hydrique du sol au moment des événements pluvieux. La persistance de la DEA dans l'eau du sol est plus longue que celle de l'atrazine, ces produits se dissipent plus lentement en profondeur. L'atténuation des concentrations en atrazine à $60 \mathrm{~cm}$ de profondeur par rapport à celles des eaux de ruissellement varie de 60 à $95 \%$, selon les années et la place de la bougie poreuse par rapport aux voies d'écoulement. Les transferts sont limités aux quelques semaines qui suivent les traitements alors que le lessivage de la DEA et de l'atrazine intervient principalement pendant la période d'arrêt de la végétation. Dans les conditions climatiques de cette étude, le lessivage calculé de la DEA est deux fois celui de l'atrazine.

atrazine / dééthylatrazine / bande herbeuse / bougie poreuse / solution du sol

Communicated by Marco Trevisan (Perugia, Italy)

* Correspondence and reprints

delphin@colmar.inra.fr 


\section{INTRODUCTION}

Vegetative filter strips (VFS) are a proven means of reducing runoff and subsequent contamination of surface water. Numerous researchers have demonstrated the effectiveness of VFS in removing sediments in suspension and in reducing minerals and organic chemicals transported in solution with runoff water. Among the mechanisms affecting VFS performance, deposition of sediments and sediment-bound contaminants and infiltration of water and solutes have been suggested to be the most important $[6,13,18,20]$. It was shown in particular that VFS efficiency in herbicide removal was mainly due to the infiltration of the runoff water into the soil [1, 10, 14].

Herbicides classified as weakly to moderately adsorbed on the soil particles are mostly transported in solution in runoff water, and concentrations are higher when rainfall events occur soon after herbicide application [24]. Vegetative filter strips installed down-slope, by changing the flow hydraulics, may increase the opportunity for infiltration in large pores, particularly in the presence of surface ponding water (bypass flow). Preferential flow is assumed to transport pesticides rapidly and deeply in the soil via macropores, especially when high rates of water inflow occur. These conditions may enhance the opportunity for leaching of incoming pesticides removed from runoff by VFS. On the other hand, the upper layer of grassland soils has a high organic matter content, mainly as non decomposed materials, and an active microbial biomass; consequently the adsorption and biodegradation of pesticides may be increased [2]. The efficiency of VFS in preventing pesticides from being leached has apparently not yet been studied, though it could represent a significant aspect of the VFS's protecting effect on water quality.

The study presented here was conducted under natural rainfall conditions. The leaching of atrazine and DEA (deethylatrazine) transported in runoff water and trapped in a VFS installed down-slope from a maize plot was monitored with suction lysimeters (porous cups) inserted in the soil. The objectives of the study were: (1) to describe pesticide leaching under the grass strip and examine field conditions controlling this phenomenon, and (2) to evaluate the impact of leaching under VFS on groundwater.

\section{MATERIALS AND METHODS}

\subsection{Field experiment}

The study was carried out in northeastern France from 1997 to 1999 on a farm plot cropped each year with maize. The soil on the site is a silt loam; soil physicochemical properties are given in Table I. Five rectangular plots were marked out on a $4 \%$ slope with their longer sides parallel to the axis of maximum slope. Each area of runoff ( 50 by $4.8 \mathrm{~m}$ ) was delimited with $25 \mathrm{~cm}$ high plastic borders driven $10 \mathrm{~cm}$ deep into the soil. The $20 \mathrm{~m}$ wide vegetative filter strip was installed on a zone of $2 \%$ slope at the base of the plots. A $4.8 \mathrm{~m}$ long gutter was installed on 4 plots in the VFS at $0,6,12$ and $18 \mathrm{~m}$ from the edge of the maize plot to collect the runoff effluents. Each runoff collector was connected by a PVC pipe to a $1000 \mathrm{~L}$ tank placed down-slope in the soil (Fig. 1). After a runoff event, the effluent was quantified, agitated and a

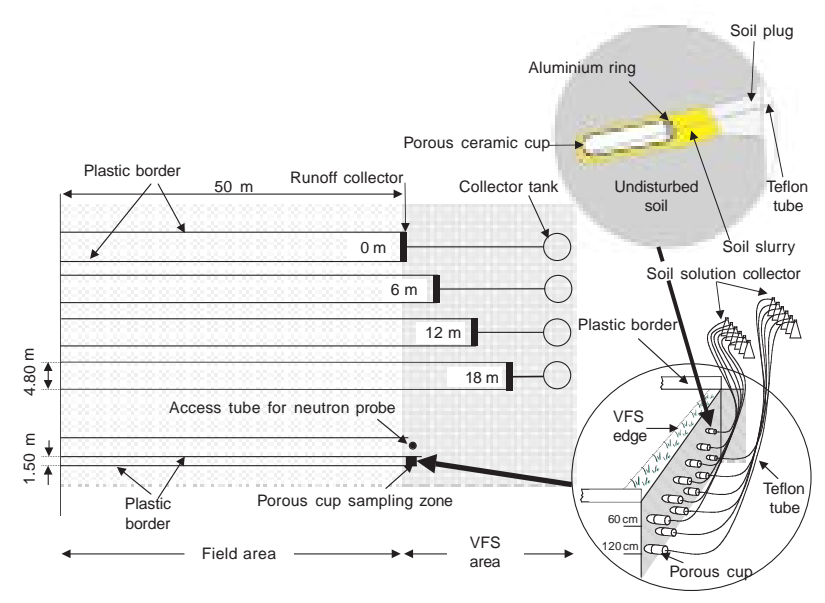

Figure 1. Field layout of the VFS experimental site.

Table I. Main soil characteristics.

\begin{tabular}{|c|c|c|c|c|c|c|c|c|c|}
\hline & Clay & Fine silt & Coarse silt & $\begin{array}{c}\text { Fine sand } \\
\mathrm{g} \cdot \mathrm{k}^{-1}\end{array}$ & Coarse sand & $\mathrm{OM}$ & Tot. carbonate & $\mathrm{pH}$ & $\begin{array}{l}\text { Bulk density } \\
\mathrm{g} \cdot \mathrm{cm}^{-3}\end{array}$ \\
\hline $0-30 \mathrm{~cm}$ & 206 & 353 & 408 & 12 & 7 & 15 & trace & 6.7 & 1.45 \\
\hline $60-90 \mathrm{~cm}$ & 236 & 368 & 384 & 7 & 0 & 5 & trace & - & 1.5 \\
\hline $120-140 \mathrm{~cm}$ & 155 & 378 & 440 & 13 & 11 & 3 & 230 & - & 1.5 \\
\hline
\end{tabular}


$2 \mathrm{~L}$ sample was taken from each tank. The tanks were emptied after each runoff event. The water samples were frozen after collection and stored until the end of the growing season before analysis.

The ceramic porous cups, 1 bar high flow, $95.9 \mathrm{~mm}$ long and $31.0 \mathrm{~mm}$ outside diameter (SDEC, France), were plugged with an epoxy resin adhesive. They were installed in the fifth plot in November 1996 under the edge of the VFS, down a $1.5 \mathrm{~m}$ wide runoff area delimited by plastic borders as shown in Figure 1. After removing the vegetative layer, a trench was dug in the soil and six porous cups were inserted $25 \mathrm{~cm}$ into the soil and sloped downwards at an angle of approximately $10^{\circ}$ at 60 and $120 \mathrm{~cm}$ depth. They were installed in an alternating arrangement so that the soil profile above each lower porous cup was undisturbed. The average horizontal distance between porous cups was $25 \mathrm{~cm}$. The trench was then refilled before putting back the vegetative layer. Each porous cup was connected by one Teflon tube ( $\varnothing 2 \mathrm{~mm}$ ) to a $2 \mathrm{~L}$ glass container placed on the soil surface, so that the soil solution extracted was continuously removed from the ceramic cup. $65 \mathrm{kPa}$ suction was applied to the container after the main runoff and/or rain events for collecting the soil solution. The soil solution sampling was repeated when possible each week. The water volume sampled from the porous cups varied up to a maximum of $1200 \mathrm{~mL}$ depending on soil moisture conditions. Generally no solution was extracted when the soil moisture was less than $85 \%$ of the water retention capacity. Soil solution samples were analyzed when the volume collected exceeded $100 \mathrm{~mL}$. Statistical analysis was therefore carried out with at most six replicates at $60 \mathrm{~cm}$ and five replicates at $120 \mathrm{~cm}$ because one porous cup ceased to work a few months after installation.

The vegetative filter strip was sown in September 1996. It was mown 4 or 5 times each year. The average strip vegetation was (in 2000) $80 \%$ ryegrass (Lolium perenne L.) and $20 \%$ white clover (Trifolium repens L.). The main cropping operations applied each year on the maize plot are presented in Table II.

The soil water content was measured with a neutron probe in an access tube set close to the porous cup area. Measurements were made to a depth of $1.2 \mathrm{~m}$ in $10 \mathrm{~cm}$ increments. The water content of the $10 \mathrm{~cm}$ surface layer was determined by gravimetric sampling. The water holding capacity was estimated for each $10 \mathrm{~cm}$ layer from the average of five measurements of the soil water content during winter (1997-98) a few days after rainfall events. The bulk density was determined using cylindrical metal core samplers driven horizontally into the soil. A Pulsia automated weather station (Pulsonic) was installed in 1998 on the site to monitor the rainfall and the climatic variables used to compute Penman potential evapotranspiration (PET). In 1997 only the rainfall (amount and intensity) was monitored in situ: PET values provided by the nearest meteorological station (22 km away) were used. Infiltration at the top of the VFS plot was determined for each runoff event from the inflow volumes measured at $0,6,12$ and $18 \mathrm{~m}$ in the strip, assuming that they decreased linearly in the grass. The STICS model [3] was used to predict the water flux draining out of the soil at $120 \mathrm{~cm}$ under the VFS. STICS is a model simulating the growth and development of the crop and the water and nitrogen balance of the soil-crop system. Parameters of STICS model were adjusted to experimental conditions by fitting simulation results to measurements of soil water storage in 1997.

\subsection{Analytical procedures}

Water samples collected by the porous cups were stored at $4-6{ }^{\circ} \mathrm{C}$ for a maximum of one week before extraction and analysis. Sediments in the runoff effluents were removed by centrifugation. Water samples were extracted using SPE cartridges LiCholut RP 18 (500 mg) Merck. The extracted volume varied from 100 to $500 \mathrm{~mL}$ depending on the sample size. The cartridge was eluted with $2 \mathrm{~mL}$ methanol. The extraction recoveries ranged from 88 to $112 \%$ for atrazine and 100 to $114 \%$ for DEA.

Concentrations of atrazine and DEA in the extract were determined using a Waters HPLC system equipped with a UV detector at $220 \mathrm{~nm}$. The compounds were separated on a Nucleosil $12010 \mathrm{C} 18(10 \mu \mathrm{m}, 250 \times 4.6 \mathrm{~mm})$ column by using a flow rate of $1.5 \mathrm{~mL} \cdot \mathrm{min}^{-1}$. The mobile phase was a mixture of water and acetonitrile in linear gradient varying over 22 minutes from 90-10 (vol./vol.) at the start of the run to 35-65 at the end [22]. The injection volume was $50 \mu \mathrm{L}$. The detection limit of atrazine and DEA determination by HPLC in the extract was $0.025 \mu \mathrm{g} \cdot \mathrm{mL}^{-1}$; the corresponding detection limit in the water sample was dependent on the extracted volume: $0.1 \mu \mathrm{g} \cdot \mathrm{L}^{-1}$ for a $500 \mathrm{~mL}$ sample.

\section{RESULTS AND DISCUSSION}

\subsection{Atrazine and DEA in soil solution}

Perrin-Ganier et al. [16] showed in a laboratory test that, when collecting an atrazine solution using porous cups, a decrease in the pesticide concentration in the extracted water was observed only in the first 10 milliliters collected. In view of the large volumes collected at each sampling date, the concentration of the extracted solution was assumed to be close to that of the external solution. As soil solution sampling is generally carried 
Table II. Maize cropping characteristics and main runoff events.

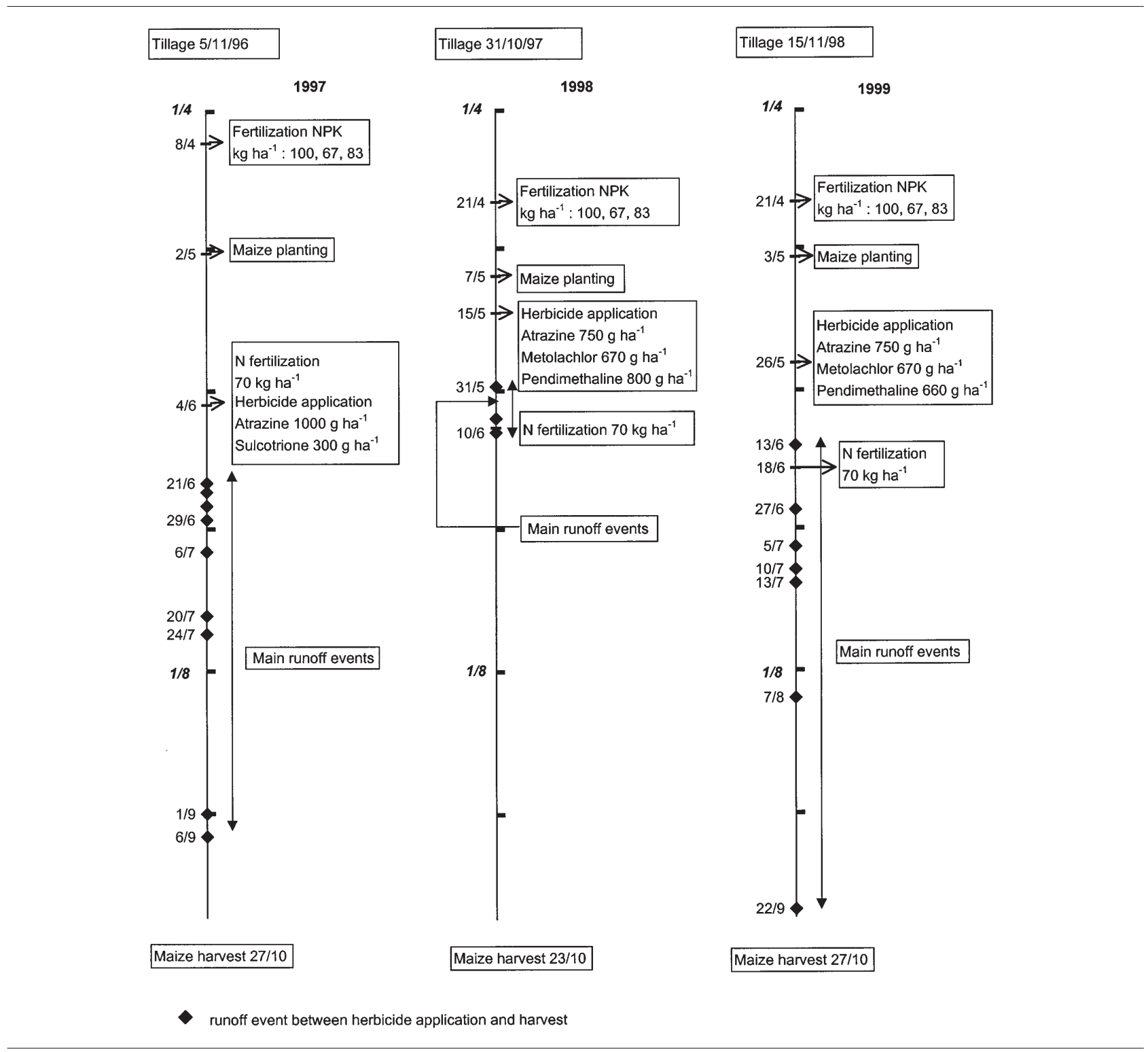

out at least several hours after rain events, porous cups extract mainly water weakly retained in the soil pores and its pollutant content is the result of partial solute exchange between mobile and immobile (or weakly mobile) water.

\subsubsection{Spatial variability}

Atrazine concentrations around $0.1 \mu \mathrm{g} \cdot \mathrm{L}^{-1}$ in the soil solution generally exhibited high variability, probably because these values were close to the analytical detection limit. Regardless of these values, the mean coefficient of variation of atrazine concentration between porous cups over 3 years was $57 \%$ at $60 \mathrm{~cm}$ depth and $45 \%$ at $120 \mathrm{~cm}$ and tended to increase during concentration peaks. The CV of DEA concentration was lower, $35 \%$ and $28 \%$ at $60 \mathrm{~cm}$ and $120 \mathrm{~cm}$ respectively. The variability of atrazine and DEA concentration in the soil solution may result from the heterogeneity of water flow in the soil as shown by studies using dyes [8] and also 
from the mobility of the chemicals in relation to retention by soil components. The decrease in atrazine variability with depth could be partly explained by the decrease of soil organic matter content and the subsequent increase in pesticide mobility. The higher mobility of DEA in comparison with atrazine [19] could result in its more homogeneous distribution in the soil solution.

\subsubsection{Time trends}

As shown in Figure 2, the atrazine concentration in the soil solution under the VFS at the beginning of the experiment was low at $60 \mathrm{~cm}$ depth and slightly higher at $120 \mathrm{~cm}$; it remained nearly constant or slowly decreasing before the first runoff events. The same trends were observed for DEA with still higher values. The concentration of atrazine and DEA measured in the soil solution could be due to migration and persistence of previous herbicide applications on maize.

In 1997 and 1999, the atrazine concentration at $60 \mathrm{~cm}$ increased immediately after the first runoff event. The total amounts of water (rainfall plus runoff effluent) removed by the VFS during the first runoff event did not replenish the soil water deficit which was $42 \mathrm{~mm}$ and $9 \mathrm{~mm}$ in 1997 and 1999 respectively at the end of the first sampling date. The maximum atrazine concentration appeared in the soil solution 15 days after the first runoff event (third sampling date) in 1997 and at the first sampling date in 1999. The soil water content was then close to field capacity. In 1998 the deficit was $53 \mathrm{~mm}$ after the first runoff event and remained greater than $30 \mathrm{~mm}$ till the maize harvest. At $120 \mathrm{~cm}$ the concentration increase was delayed for approximately one week, the maximum being reached 1-3 months later. Similarly, the DEA concentration in the soil solution at $60 \mathrm{~cm}$ increased rapidly after the first runoff event but at a lower rate than atrazine, the maximum occurring approximately one month later. A sharp peak of DEA concentration was observed in addition immediately after the first runoff event in 1999. At $120 \mathrm{~cm}$, DEA increase was spread over 1 to 4 months.

In 1997 and 1999 under VFS, the rapid increase in atrazine concentration in the soil solution at $60 \mathrm{~cm}$ after the first runoff event could be the consequence of preferential transport, since atrazine moved deeper than expected. In 1997, no DEA peak was observed, probably because of the similarity between DEA concentrations in runoff effluents and in the soil solution at $60 \mathrm{~cm}$ (Fig. 4). The sharp peak of DEA occurring in 1999 may be attributed to preferential transport, as the DEA concentration
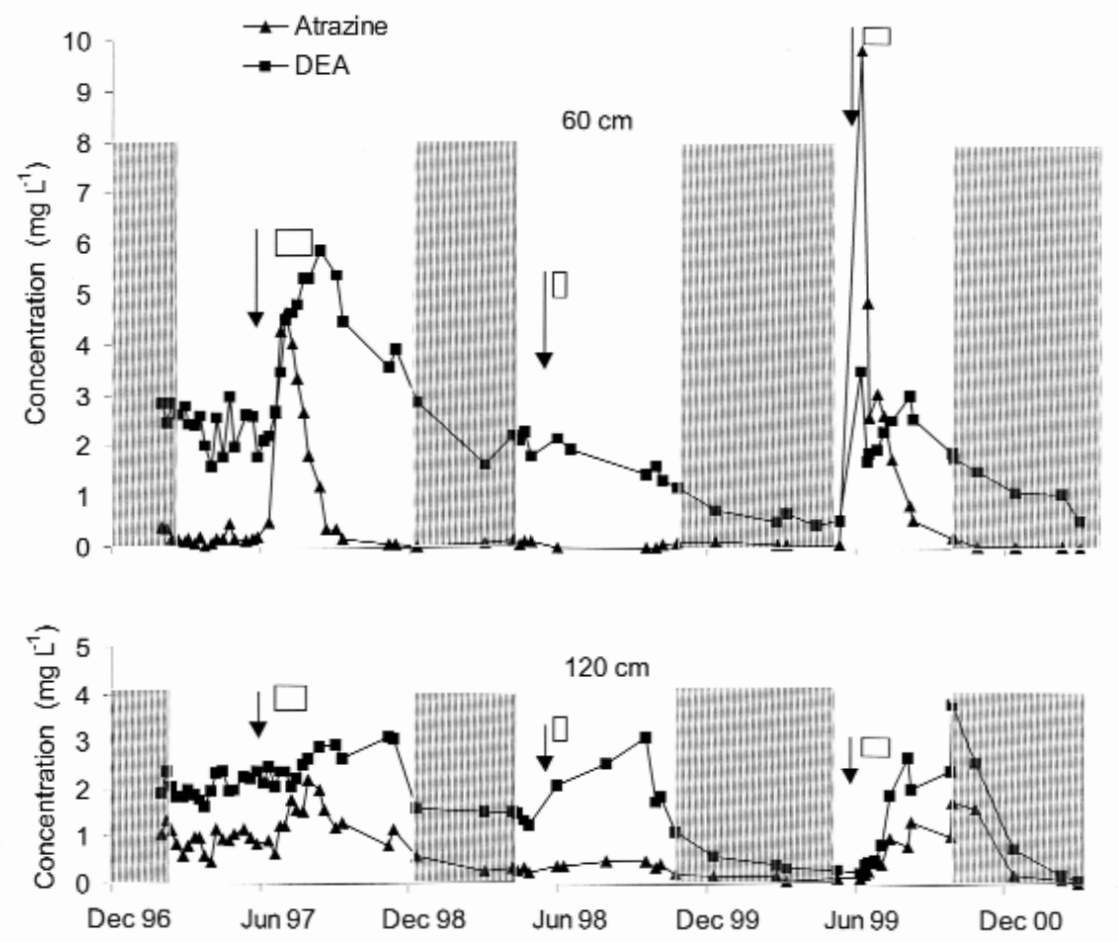

Figure 2. Variation of atrazine and DEA concentration in the soil solution under the VFS (arrow = atrazine application; rectangle $=$ period of first runoff events, shaded $=$ draining period). 
in runoff effluents was much higher than in the soil solution at $60 \mathrm{~cm}$ before the first infiltration event. Despite the lack of water sampling due to low soil moisture from mid-June to October 1998, it can be reasonably assumed that pesticide migration after runoff events had not reached $60 \mathrm{~cm}$ depth, because no release of DEA was observed at the end of summer as in 1997 and 1999 when pesticide was transported below $60 \mathrm{~cm}$. The infiltration depth of preferential flow seemed to be influenced by the water deficit after the infiltration event. On the other hand, the pattern of inflow plus rainfall during the runoff events may probably also be involved.

At $120 \mathrm{~cm}$ the atrazine peak was reached 1-2 months later than at $60 \mathrm{~cm}$. This delay is not consistent with the hypothesis of preferential transport for pesticide. It may therefore be assumed that only a very limited number of preferential flows penetrated up to $120 \mathrm{~cm}$ in the soil; the response delay would represent the time for atrazine to reach the solution collecting points by diffusion, by water migration down moisture gradients or with the water flow generated by the partial vacuum applied in the porous cups. The diffusion capacity of atrazine in the soil solution is not well known at present. Results obtained under experimental conditions rather similar to ours showed that the radius of influence of porous cups for water flow was approximately $20 \mathrm{~cm}$ [27].

In 1998 the soil water content at $60 \mathrm{~cm}$ was low (Fig. 3) and no soil solution was collected at $60 \mathrm{~cm}$ depth in the porous cups after the runoff events up to the end of summer. Atrazine concentration remained very low over the year in the soil solution and DEA concentration in
October was consistent with the declining trend observed after the maximum reached in 1997 . At $120 \mathrm{~cm}$ however DEA concentration rose during the summer: a similar trend was observed for atrazine but to a lesser extent (Fig. 2). The increase in DEA concentration in the soil solution observed at $120 \mathrm{~cm}$ in summer 1998 could not be explained as the result of leaching from upper soil layers since no drainage occurred during this period (Fig. 3). Previous investigations showed that a fraction of bound residues of pesticide and metabolites could be released $[9,17]$ and become available in the soil solution. However, bound residues are mainly formed in the upper soil layer. Though the VFS plot was previously cropped with maize and treated regularly with atrazine for at least 10 years, the accumulation of bound residues by leaching would perhaps not be sufficient to release the amounts of DEA measured at $120 \mathrm{~cm}$ in our experiment. DEA concentration increase occurred between the end of the spring draining period and the start of the next one in fall 1998. This increase could be interpreted as the result of a slow diffusion of DEA from the immobile water with higher DEA concentration to the weakly retained water extracted by porous cups. This phenomenon would be attenuated at $60 \mathrm{~cm}$ by more drastic adsorption of DEA on soil organic matter and by lower water content.

The maximum DEA concentration occurred at the end of atrazine decline, except at $120 \mathrm{~cm}$ in 1999. Concentration curves in 1997 and 1999 at $60 \mathrm{~cm}$ may be related to the fact that DEA is one of the degradation products of atrazine.

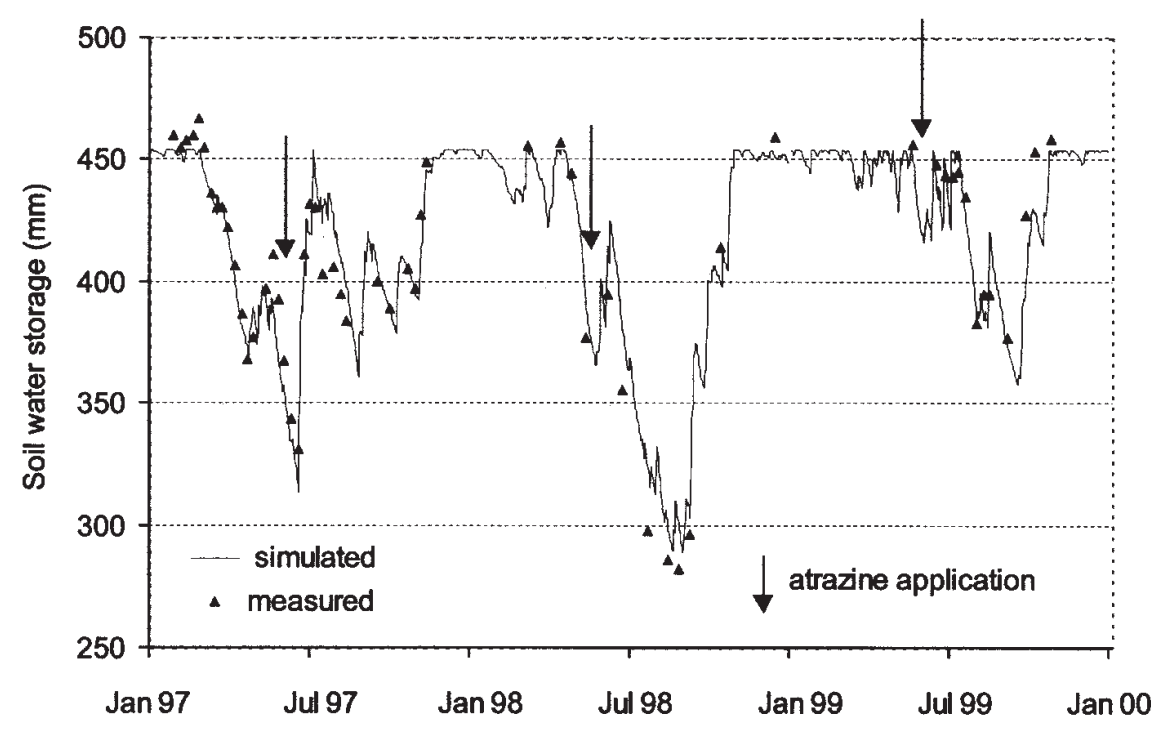

Figure 3. Simulated by STICS model and measured soil water storage in the profile $(120-\mathrm{cm})$ under the VFS $(0 \mathrm{~m})$. 


\subsubsection{Dissipation rate}

Half-life dissipation was estimated by fitting the decreasing curves of atrazine and DEA concentration in the soil solution collected by each porous cup to a first order kinetic. Estimates were made in 1997 on concentration curves obtained at 60 and $120 \mathrm{~cm}$ in one year for atrazine and in two years for DEA; the data of the increased concentration observed for DEA at $120 \mathrm{~cm}$ during summer in 1998 were discarded. In 1999, only the estimation of atrazine half-life at $60 \mathrm{~cm}$ was possible, because the dissipation process was still not finished for atrazine at $120 \mathrm{~cm}$ and for DEA at 60 and $120 \mathrm{~cm}$. The mean half-life and standard deviation for atrazine dissipation was $19 \mathrm{~d}(\mathrm{SD}=7 \mathrm{~d})$ at $60 \mathrm{~cm}$ and $85 \mathrm{~d}(\mathrm{SD}=$ $49 \mathrm{~d})$ at $120 \mathrm{~cm}$; DEA values were higher and similar at both depths: $148 \mathrm{~d}(\mathrm{SD}=48 \mathrm{~d})$ and $150 \mathrm{~d}(\mathrm{SD}=37 \mathrm{~d})$ respectively.

Dissipation of atrazine and metabolites in the soil are generally attributed to the formation of bound residues, biological and chemical degradation, plant uptake, diffusion in the soil water and possibly leaching. Half-life for atrazine dissipation in the soil cited in the literature varied widely according to experimental conditions. The values obtained in this study are consistent with values reported in databases [23]. The increase in atrazine halflife at $120 \mathrm{~cm}$ may be related to the variation with depth of the factors controlling the disappearance of the pesticide in the soil: soil organic matter and clay content, soil $\mathrm{pH}$, microbial biomass and root density. Kruger et al. $[11,12]$ attributed shorter persistence of atrazine in upper soil layers in comparison with subsurface soil after incubation mainly to lower formation of residues bound to soil organic matter and to reduction of biodegradation. In our experiment, dissipation half-life for DEA was significantly higher than for atrazine at $60 \mathrm{~cm}$. Only a few references report on DEA persistence in the soil. Kruger et al. [12] found no differences in the degradation rate between atrazine and DEA. Similar conclusions were drawn from results reported by Winkelmann and Klaine $[25,26]$. Differences in plant uptake between atrazine and DEA were not relevant to explaining the half-life differences. The longer persistence of DEA in the soil solution at $60 \mathrm{~cm}$ could be attributed to a lower capacity to form bound residues. Capriel et al. [4] reported that atrazine was present to a greater extent than DEA in bound residues, but most studies suggested that DEA produced more or equal amounts of nonextractable residues than atrazine $[15,19,25,26]$. Another possible explanation could be that the DEA dissipation rate was underestimated as a result of real DEA disappearance plus DEA formation as a metabolite of atrazine degradation and equilibrium processes between concentrations in immobile and in weakly mobile soil water.

\subsubsection{Fall in concentration with depth}

Concentrations of atrazine and DEA in the runoff effluents are presented in Figure 4. The fall in atrazine concentration with depth was calculated by the ratio $\mathrm{R}$ between maximum concentration in the soil solution at $60 \mathrm{~cm}$ and in the effluents during the first runoff events. In 1997 (20/6-23/7), R varied from 3 to 40\%, according to the porous cup position. From $14 / 6$ to $8 / 7$ 1999,
Figure 4. Variation of atrazine and DEA concentration in the runoff water (0 m collector).

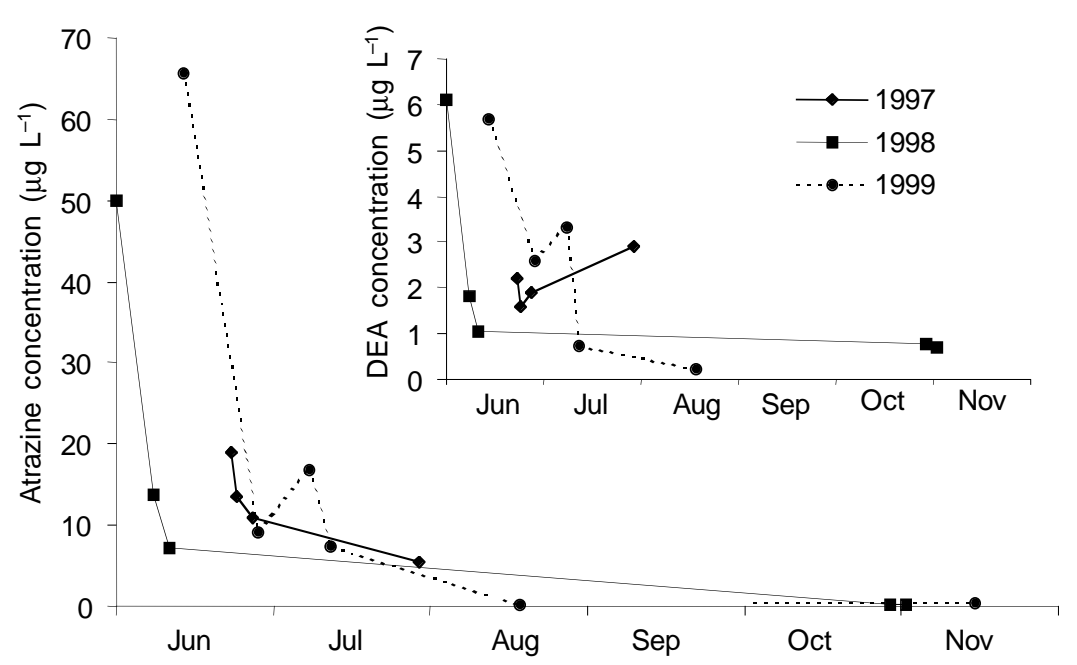


atrazine concentration in the soil solution at $60 \mathrm{~cm}$ was 3 to $19 \%$ of the concentration in the runoff water. Edwards et al. [7] reported a similar reduction for atrazine concentration measured directly at $45 \mathrm{~cm}$ in the solution flowing in earthworm and artificial burrows. In a similar experiment Stehouwer et al. [21] found less attenuation. Results however seem to be strongly dependent on experimental conditions and on the methods used for sampling soil solution. During preferential flow, atrazine concentrations in the soil solution collected by porous cups would underestimate those in water moving rapidly in the macropores. One reason is that atrazine concentration in the soil solution collected by porous cups is the result of water dispersion in micropores and possibly of atrazine diffusion from mobile water into weakly retained water. A second is that porous cups, owing to their radius of influence, may collect water in areas with various degrees of contamination by chemicals.

\subsection{Estimation of atrazine and DEA leaching}

\subsubsection{Estimation of drainage}

Hydraulic data collected on the VFS plot are presented in Table III. Annual rainfall amounts were similar in 1997 and 1998 and lower than normal, whereas in 1999 they were above average. Runoff events were observed more frequently in late spring and in summer and accounted for approximately $2 \%$ of the rainfall. These events however carried substantial amounts of water into the VFS and caused extra infiltration ranging from $4 \%$ to $11 \%$ of the rainfall. Annual drainage estimated by STICS model occurred, as expected, mainly outside times of crop growth. Water losses by drainage during the growing season were limited in 1997 and 1999 or absent in 1998 .

\subsubsection{Estimation of atrazine and DEA losses by leaching}

Leaching of atrazine and DEA were estimated from concentrations in the soil water collected via porous cups at $120 \mathrm{~cm}$ and from water losses by drainage as calculated by the STICS model. As shown previously in this paper, there was only a low probability of preferential flow reaching $120 \mathrm{~cm}$ in the soil; chemicals might therefore be transported by piston flow in water moving slowly in fine pores. On the other hand, the greater mobility and persistence of atrazine and DEA at this depth suggests that an equilibrium of solute concentration might become established between mobile and quasi-immobile water. Nevertheless, a negative or positive bias, according to environmental conditions, cannot be excluded.

Table III. Hydrologic analysis and pesticide leaching estimated at the top of the VFS plot.

\begin{tabular}{|c|c|c|c|c|c|c|}
\hline & \multirow[t]{2}{*}{ Rainfall } & \multirow[t]{2}{*}{ Runoff $^{1}$} & \multirow{2}{*}{$\begin{array}{c}\text { Inflow }^{2} \\
\text { infiltration } \\
\mathrm{mm}\end{array}$} & \multirow[t]{2}{*}{ Drainage $^{3}$} & \multicolumn{2}{|c|}{ Leaching $^{4}$} \\
\hline & & & & & atrazine & DEA \\
\hline \multicolumn{7}{|l|}{1997} \\
\hline before atrazine application & 265 & 5 & 26 & 105 & 1460 & 2580 \\
\hline during maize growth & 360 & 8 & 56 & 9 & 100 & 210 \\
\hline after harvest & 193 & 1 & 5 & 82 & 490 & 1310 \\
\hline over all year & 818 & 14 & 87 & 196 & 2050 & 4100 \\
\hline \multicolumn{7}{|l|}{1998} \\
\hline before atrazine application & 240 & 1 & 6 & 99 & 410 & 1480 \\
\hline during maize growth & 423 & 5 & 27 & 0 & 0 & 0 \\
\hline after harvest & 193 & 11 & 25 & 118 & 240 & 1320 \\
\hline over all year & 856 & 17 & 58 & 217 & 650 & 2800 \\
\hline \multicolumn{7}{|l|}{1999} \\
\hline before atrazine application & 409 & 3 & 5 & 197 & 270 & 730 \\
\hline during maize growth & 442 & 20 & 31 & 12 & 60 & 60 \\
\hline after harvest & 226 & 1 & 3 & 199 & 2580 & 5960 \\
\hline over all year & 1078 & 24 & 39 & 408 & 2910 & 6750 \\
\hline
\end{tabular}

${ }^{1}$ runoff expressed as mm over source area ( 0 m collector $)$.

${ }^{2}$ runoff volume removed by VFS, converted to mm taking into account decrease in the grass strip.

${ }^{3}$ drainage calculated by STICS model.

${ }^{4}$ leaching estimated from drainage volume and chemical concentration in the soil solution at $120 \mathrm{~cm}$. 
The leaching amounts calculated are proposed as being within an order of magnitude.

Approximately half as much atrazine as DEA was lost by leaching under VFS. This was due to the higher concentration of DEA in the soil solution because of its persistence at $120 \mathrm{~cm}$. Annual losses of atrazine plus DEA ranged from $3400 \mathrm{mg} \cdot \mathrm{ha}^{-1}$ to $9600 \mathrm{mg} \cdot \mathrm{ha}^{-1}$, however, part of these leaching pesticides were applied more than one year ago. These results may be due to the weather conditions on the experimental site, with rainfall exceeding potential evapotranspiration and subsequent drainage accentuated by water inflow as runoff effluent onto the grass strip. It has been shown in a previous lysimeter experiment that, owing to the persistence of DEA in the subsoil, intensive irrigation led to large and prolonged losses of DEA by leaching [5]. Despite high atrazine and DEA concentrations in the soil solution during maize growth, losses by leaching in summer remained limited ( 0 to $5 \%$ of the annual losses).

\section{CONCLUSION}

In our experimental conditions, a significant proportion of atrazine and DEA transported in runoff effluent from a maize crop and removed by a vegetative filter strip was lost by leaching. In view of these results, the risk of pesticide leaching can be described in two steps.

The first step is marked by the possibility of preferential migration in the soil of the chemicals transported in runoff effluents into the VFS soon after herbicide application. The initial water content of the soil and the capacity of the rainfall events and subsequent runoff effluents to replenish the soil water deficit would mainly influence the migration depth and the reduction in concentration of the percolating solution. The migration depth will condition the later dissipation rate of atrazine and DEA in the soil and thereby their capacity to contaminate groundwater by leaching. Whatever the depth, DEA appeared to be more persistent than atrazine in the soil solution. Owing to the intensive evapotranspiration of the grass strip, leaching of pesticide is generally limited during the growth period.

The second step occurs mainly outside the vegetation growing season. The pesticide and metabolite, which remain in the soil solution according to their chemical properties and their position in the soil profile, will be transported deeper by the draining water. It is mainly the volume of drainage in relation to environmental conditions which influences this step. In the conditions of this experiment, DEA may represent a source of groundwater contamination which is twice as great as that of atrazine.
Atrazine and DEA leaching under a VFS seems to be dependent on the annual water balance sheet. Weather conditions with a small water surplus may reduce pesticide leaching under a VFS owing to the limited amounts of water draining and to the greater delay occurring before the start of drainage. Another determining factor controlling pesticide leaching under VFS would be the initial soil dryness at the start of runoff events; it may be increased by ensuring optimal growing conditions for the grass strip.

Acknowledgments: This work was financially supported by the Alsace Regional Council, the Haut-Rhin General Council, the Cereal and Oilseed Producer Association of the Haut-Rhin (APCO) and the Protection against Crop Pest Regional Association (FREDECA). We thank J.-L. Meyer and G. Schwab for technical assistance in the field, C. Schneider, F. Tourrel and D. Hartmann for analysis and R. Trendel for model calculation. Thanks are also due to D. Lasserre and $M$. Remuaux of the Technical Institute for Cereals and Forage (ITCF) for runoff measurements and R. Koller of the Agronomy Improvement Association in Alsace (ARAA).

\section{REFERENCES}

[1] Arora K., Mickelson S.K., Backer J.L., Tierney D.P., Peters C.J., Herbicide retention by vegetative buffer strips from runoff under natural rainfall, Trans. ASAE 39 (1996) $2155-2162$.

[2] Benoit P., Barriuso E., Vidon P., Réal B., Isoproturon sorption and degradation in a soil from grassed buffer strip, J. Environ. Qual. 28 (1999) 121-129.

[3] Brisson N., Mary B., Ripoche D., Jeuffroy M.H., Ruget F., Nicoullaud B., Gate P., Devienne-Barret F., Antonioletti R., Durr C., Richard G., Beaudoin N., Recous S., Tayot X., Plenet D., Cellier P., Machet J.M., Meynard J.M., Delécolle R., STICS: a generic model for the simulation of crops and their water and nitrogen balances. I. Theory and parameterization applied to wheat and corn, Agronomie 18 (1998) 311-346.

[4] Capriel P., Haisch A., Khan S.U., Distribution and nature of bound (nonextractable) residues of atrazine in a mineral soil nine years after the herbicide application, J. Agric. Food Chem. 33 (1985) 567-569.

[5] Chapot J.-Y., Delphin J.E., Movement of atrazine through a lyzimeter fitted with porous cups under intensive irrigation, in: Zima M. , Bartosova M.L. (Eds.), Proc. fifth ESA Congress, Nitra, 1998, pp. 208-209.

[6] Dillaha T.A., Reneau R.B., Mostaghimi S., Lee D., Vegetative filter strips for agricultural nonpoint source pollution control, Trans. ASAE 32 (1989) 513-519.

[7] Edwards W.M., Shipitalo M.J., Traina S.J., Edwards C.A., Owens L.B., Role of Lumbricus terrestris (L.) burrows on quality of infiltrating water, Soil Biol. Biochem. 24 (1992) 1555-1561. 
[8] Ghodrati M., Jury W.A., A field study using dyes to characterize preferential flow of water, Soil Sci. Soc. Am. J. 54 (1990) 1558-1563.

[9] Hayar S., Munier-Lamy C., Chone T., Schiavon M., Physico-chemical versus microbial release of $14 \mathrm{C}$-atrazine bound residues from a loamy clay soil incubated in laboratory microcosms, Chemosphere 34 (1997) 2683-2697.

[10] Klöppel H., Kördel W., Stein B., Herbicide transport by surface runoff and herbicide retention in a filter strip-rainfall and runoff simulation studies, Chemosphere 35 (1997) 129-141.

[11] Kruger E.L., Rice P.J., Anhalt J.C., Anderson T.A., Coats J.R., Comparative fates of atrazine and deethylatrazine in sterile and nonsterile soils, J. Environ. Qual. 26 (1997) 95-101.

[12] Kruger L.E., Somasundaram L., Kanvar R.S., Coats J.R., Persistence and degradation of [14C] atrazine and [14C] deisopropylatrazine as affected by soil depth and moisture conditions, Environ. Toxicol. Chem. 12 (1993) 1959-1967.

[13] Lim T.T., Edwards D.R., Workman S.R., Larson B.T., Dunn L., Vegetated filter strip removal of cattle manure constituents in runoff, Trans. ASAE 41 (1998) 1375-1381.

[14] Misra A.K., Baler J.L., Mickelson S.K., Shang H., Contributing area and concentration effects on herbicide removal by vegetative buffer strips, Trans. ASAE 39 (1996) 2105-2111.

[15] Moreau C., Mouvet C., Sorption and desorption of atrazine, deethylatrazine, and hydroxyatrazine by soil and aquifer solids, J. Environ. Qual. 26 (1997) 416-424.

[16] Perrin-Ganier C., Schiavon M., Portal J.M., Babut M., Breuzin C., Alteration of pesticide content in the soil solution collected by a porous cup, Chemosphere 29 (1994) 63-70.

[17] Pignatello J.J., Huang L.Q., Sorptive reversibility of atrazine and metolachlor residues in field soil samples, J. Environ. Qual. 20 (1991) 222-228.
[18] Robinson C.A., Ghaffarzadeh M., Cruse R.M., Vegetative filter strip effects on sediment concentration in cropland runoff, J. Soil Water Cons. 50 (1996) 227-230.

[19] Schiavon M., Studies of the movement and the formation of bound residues of atrazine, of its chlorinated derivatives, and of hydroxyatrazine in soil using $14 \mathrm{C}$ ring-labelled compounds under outdoor conditions, Ecotoxicol. Environ. Safety 15 (1988) 55-61.

[20] Srivastava P., Edwards D.R., Daniel T.C., Moore P.A., Costello T.A., Performance of vegetative filter stips with varying pollutant source and filter strip lengths, Trans. ASAE 39 (1996) 2231-2239.

[21] Stehouwer R.C., Dick W.A., Traina S.J., Sorption and retention of herbicides in vertically oriented earthworm and artificial burrows, J. Environ. Qual. 23 (1994) 286-292.

[22] Steinheimer T.R., HPLC determination of atrazine and principal degradates in agricultural soils and associated surface and ground water, J. Agric. Food Chem. 41 (1993) 588-595.

[23] Wauchope R.D., Buttler T.M., Hornsby A.G., Augustijn-Beckers P.M.W., Burt J.P., The SCS/ARS/CES pesticide properties database for environmental decision-making, Rev. Environ. Contam. Toxicol. (1992) 1-164.

[24] Webster E.P., Shaw D.R., Impact of vegetative filter strips on herbicide loss in runoff from soybean (Glycine max), Weed Sci. 44 (1996) 662-671.

[25] Winkelmann D.A., Klaine S.J., Degradation and bound residue formation of atrazine in a western Tennessee soil, Environ. Toxicol. Chem. 10 (1991) 335-345.

[26] Winkelmann D.A., Klaine S.J., Degradation and bound residue formation of four atrazine metabolites, deethylatrazine, deisopropylatrazine, dealkylatrazine and hydroxyatrazine, in a western Tennessee soil, Environ. Toxicol. Chem. 10 (1991) 347-354.

[27] Wu L., Baker J.M., Allmaras R.R., Numerical and field evaluation of soil water sampled by suction lysimeters, J. Environ. Qual. 24 (1995) 147-152.

To access this journal online: www.edpsciences.org 